\title{
Dinâmicas socioeconômicas dos feirantes agricultores familiares de Chapecó (SC)
}

\author{
HIEDA MARIA PAGLIOSA CORONA \\ Universidade Tecnológica Federal do Paraná \\ SAMUEL TAFERNABERRI VASQUES \\ Prefeitura Municipal de Chapecó \\ WILSON ITAMAR GODOY \\ Universidade Tecnológica Federal do Paraná
}

\begin{abstract}
Resumo
No presente artigo, o objetivo central é compreender a feira-livre como um espaço estratégico para a permanência da agricultura familiar, indo além da temática da inserção de mercado. A pesquisa de campo foi desenvolvida nas duas feiras-livres centrais da cidade de Chapecó/SC, dividida em duas etapas: levantamento das características dos feirantes, por meio da entrevista com base em um formulário com questões abertas e fechadas com 63 feirantes responsáveis pelas bancas; e entrevistas com base em questões semiestruturadas com as 28 famílias que se enquadraram como feirantes agricultores familiares residentes no Município de Chapecó. Os dados coletados foram apresentados em quadros sínteses e a análise realizada seguiu os parâmetros da análise de conteúdo. Os resultados demostram a importância desse mercado de proximidade para os agricultores familiares feirantes, não apenas como espaço de comercialização de produtos, mas como espaço de construção social em que estão presentes as relações de interconhecimento, de reciprocidade e de relativa autonomia frente ao sistema agroalimentar hegemônico.

Palavras-chave: Feirantes agricultores familiares. Inserção nos mercados. Mercados de proximidade. Estratégias de resistência. Autonomia.
\end{abstract}




\title{
Socioeconomic dynamic in market practices of family farmers Chapecó (SC)
}

\begin{abstract}
In this article the central objective is to understand the fair as a strategic space for the survival of family farming, going beyond the issue of market integration. Field research was conducted in two main fairs in the city of Chapeco/SC, divided into two stages: a study of the characteristics of the market traders, through the interview based on a form with open and closed questions 63 hawkers responsible posts; and interviews from semi-structured questions with 28 families, who met the exigencies of family farmers and are marketer Chapecó residents. The collected data are presented in tabular summaries and analysis followed the content analysis parameters. The results demonstrate the importance of local farmers market vendors not only as a space for marketing of products, but as a social construction of space that are current interconhecimento relations, reciprocity and the relative autonomy of the food hegemonic system.

Keywords: Family farming. Near Market. Insertion into markets. Strategies. Autonomy.
\end{abstract}

\section{Dinámicas socioeconómicas de los feriantes agricultores familiares de Chapecó (SC)}

\section{Resumen}

El presente artículo intentará entender cómo la feria libre es un espacio estratégico para la permanencia de la agricultura familiar, además de la temática de la inserción del mercado. La investigación de campo fue desarrollada en las dos ferias libres centrales de la ciudad de Chapecó/SC, dividida en dos etapas: levantamiento de las características de los feriantes, a través de una entrevista apoyada por un formulario que contenía cuestiones abiertas y cerradas aplicadas a 63 feriantes responsables de los puestos de comercialización; y entrevistas basadas en cuestiones semiestructuradas aplicadas a las 28 familias, que se encuadraron como feriantes agricultores familiares residentes en el municipio de Chapecó. Los datos recolectados fueron presentados en cuadros, síntesis y el análisis realizado siguió los parámetros del análisis de contenido. Los resultados demuestran la importancia de este mercado de proximidad a los agricultores familiares feirantes no sólo como espacio de comercialización de productos, sino como espacio de construcción social en que están presentes las relaciones de interconexión, de reciprocidad y de relativa autonomía frente al sistema agroalimentario hegemónico.

Palabras llave: Feirantes agricultores familiares. Inserción en los mercados. Mercados de proximidad. Estrategias de resistencia. Autonomía. 


\section{Introdução}

A inserção de agricultores familiares nas redes agroalimentares tiveram profundas mudanças com a ampliação das políticas liberais e da hegemonia do mercado globalizado. $\mathrm{O}$ modelo hegemônico de modernização da agricultura difundido globalmente a partir da Revolução Verde, assim como da inserção dos chamados impérios agroalimentares ${ }^{1}$, acaba pressionando e excluindo os agricultores familiares (PLOEG, 2008).

Por agricultores familiares, entende-se as famílias que produzem sua existência vinculada à reprodução de um modo de vida alicerçado na relação indissociável entre trabalho, família e unidade produtiva da agricultura (LAMARCHE, 1994, WANDERLEY, 1996).

Para Wanderley (1996), a agricultura familiar tem uma lógica inseparável entre a família, o trabalho e a propriedade que trazem características das formas sociais camponesas. Essas características implicam no estabelecimento de relações sociais internas e externas peculiares e que remetem ao modo de vida desses agricultores, em que a capacidade de adaptação aos mais diferentes contextos econômicos, sociais e políticos é ressaltada.

Mendras (1976) alertava, nos anos 1960 e 1970, para as mudanças que ocorriam no mundo camponês com a modernização da agricultura e sua inserção no mercado, pois esses tenderiam a perder a autonomia tradicional, a se transformar em produtor e consumidor no/e pelo mercado, deixando de produzir para o consumo da família e para uso na unidade produtiva.

No entanto, estudos sobre as estratégias dos agricultores familiares para inserção e construção de mercados apontam para possibilidades diversas, entre elas, as feiras-livres. São importantes não apenas na perspectiva econômica, mas principalmente como proposta de manutenção de um modo de vida em que a autonomia, mesmo que relativa, frente aos impérios alimentares seja mantida. Essa estratégia de sobrevivência, por parte dos agricultores familiares, tem sido denominada de inserção em "mercados de proximidade" (WILKINSON, 2008) ou "mercados aninhados" (PLOEG, 2011).

É neste contexto, que o presente artigo se situa, pois tem como objetivo geral compreender a feira-livre como um espaço estratégico para a permanência da agricultura familiar, considerando a dinâmica de relações entre o local e o global, indo além da temática da inserção de mercado. A escolha das duas feiras-livres centrais de Chapecó permitiu evidenciar em que medida as estratégias destes feirantes contém as pressões

1 Segundo Ploeg

(2008), o império agroalimentar é "[...] um modo de ordenamento que tende a tornar-se dominante". Nesse caso, a dominação acontece com o controle dos setores que envolvem a produção, os insumos, financiamentos, a distribuição, o processamento e a comercialização junto ao setor agrícola e alimentar. 
pela inserção econômica nos mercados e, ao mesmo tempo, a manutenção de aspectos da tradição destas famílias.

A pesquisa desenvolvida tem caráter qualitativo, com fase exploratória e análise descritiva. Exploratória uma vez que objetivou descrever características do problema, ou do fenômeno a ser explicitado (GIL, 2002), para posterior escolha que permitisse o desenvolvimento da pesquisa. Nessa fase, buscou-se levantar o quadro geral das características de todos os feirantes das duas feiras centrais de Chapecó, como também o acompanhamento cotidiano das suas práticas pela observação indireta para, então, identificar os feirantes agricultores familiares do Município de Chapecó, os quais foram posteriormente entrevistados. Essas entrevistas foram realizadas entre abril e maio de 2015 .

$\mathrm{Na}$ fase exploratória, levou-se em conta o cadastro da Secretaria de Desenvolvimento Rural e Meio Ambiente-SEDEMA de 2015, no qual constava um total de 63 famílias responsáveis pelas 98 bancas ativas nas feiras coloniais e agroecológicas de Chapecó. Dessas, 39 famílias de feirantes atendiam aos critérios de enquadramento como agricultores familiares residentes no Município de Chapecó. Para atender aos objetivos propostos levou-se em conta o tempo e os recursos disponíveis para a pesquisa. Por isso, foi necessário escolher as feiras-livres mais significativas, o que conduziu à realização das entrevistas da segunda fase nas duas feiras-livres centrais, totalizando 28 das 39 famílias de agricultores familiares feirantes de Chapecó (SC).

A análise das informações e dados coletados na pesquisa teve caráter descritivo, pois buscou atentamente descrever as práticas sociais rotineiras, como uma prática interpretativa do fluxo social, contida na observação, no registro e na análise de fatos que aparentemente diminutos podem estar densamente entrelaçados em especificações complexas (GEERTZ, 2008).

Para a descrição das práticas sociais e aprofundamento de um tema complexo como o proposto, utilizou-se de anotações, diário de campo, as entrevistas, as conversas, as fotografias, as gravações e os lembretes (RICHARDSON, 2008).

A análise de conteúdo partiu de um grupo de técnicas e procedimentos sistemáticos e objetivos, com análise inicial do material, exploração do material, definição das categorias, das inferências para, por fim, realizar o tratamento dos resultados, utilizando a descrição do conteúdo presente nas respostas obtidas (BARDIN, 2009) a partir das falas dos feirantes entrevistados.

Para apresentar os resultados da pesquisa, o presente artigo está estruturado em cinco partes. Além da introdução, a segunda seção trata sobre a influência da modernidade e da modernização no modo de vida de agricultores familiares. Na terceira, discute-se a inserção de agricultores familiares em cadeias curtas de comercialização, com foco nas feiras-livres. Na quarta parte, além do tratamento dos resultados a partir da análise de conteúdo contido nas gravações, caracteriza-se o local e o público deste estudo. Por fim, o quinto item apresenta as principais conclusões obtidas do decorrer desta pesquisa. 


\section{Transformações sociais na dinâmica rural e da agricultura familiar no contexto moderno, a partir da modernização}

Uma das principais rupturas que a era moderna proporciona, diante das diversas culturas e modos de vida que a antecede, está no que Touraine (1994, p. 216) chama de "a antitradição, a derrubada das convenções, a saída dos particularismos e a entrada no universalismo". Dito dessa maneira, evidencia-se a influência e a ruptura com as formas de organização social tradicionais, baseadas em relações coletivas e de confiança ${ }^{2}$ entre agentes copresentes no tempo e no espaço.

As mudanças sociais, a partir dos períodos de industrialização, foram profundas, principalmente no que se refere aos estilos de vida e relações sociais, bem como os meios de produzir e de trocar os produtos, impactando fortemente $o$ mundo rural. Tais mudanças transformaram o trabalho, o conhecimento, incluindo as formas de estabelecer certezas e de guiar escolhas, bem como as formas de se relacionar em sociedade. A modernização é entendida por Beck (2010, p. 23) como:

o salto tecnológico de racionalização e a transformação do trabalho e da organização, englobando para além disso muito mais: a mudança dos caracteres sociais e das biografias padrão, dos estilos e forma de vida, das estruturas de poder e controle, das formas políticas de opressão e participação, das concepções de realidade e das normas cognitivas.

O sistema moderno, com suas regras, leis e contratos, baseados em normas técnicas, constitui os chamados sistemas peritos $^{3}$ (GIDDENS, 1991), que sobrepôs relações de honradez e de confiança tradicionais, criando um ambiente de tensões sociais e econômicas, em que a pressão pela inserção no mercado dificulta e impacta diretamente a dinâmica de agricultores familiares. Nesse ambiente, nem todos os agentes sociais têm condições socioeconômicas para aderirem ao mercado em sua forma convencional, ou não estão dispostos a se adequar às exigências impostas, o que é tido por alguns como um desarranjo, ou "falhas de mercado" (PLOEG, 2011), o que acaba possibilitando a emergência de outras análises.

Ploeg (2011) mostra que as desigualdades sociais e espaciais, as ameaças de marginalização de agentes rurais, a destruição da biodiversidade e a perda da qualidade de vida no campo estão associadas às regras definidas e coordenadas pelos impérios agroalimentares globalizados. Ao priorizarem 0 mercado de commodities e sua logística de especialização 
produtiva excluem os agricultores de base familiar, que possuem um sistema produtivo diversificado e pluriativo.

Com a modernização, segundo Almeida (1998, p. 39), a agricultura passa a incorporar quatro elementos ou noções: de crescimento (fim da estagnação ou do atraso) como perspectiva de desenvolvimento econômico e político; de abertura, ou fim da autonomia técnica, econômica e cultural; de especialização, ou fim da polivalência, com dependência a montante e jusante da produção agrícola, com inter-relação com a sociedade global; aparecimento de um novo tipo de agricultor, individualista, competitivo e questionador da concepção orgânica de vida social e mentalidade tradicional.

No entanto, mesmo com a influência do contexto moderno sobre os agricultores ${ }^{4}$, toma-se como referência a hipótese de Wanderley (1996), de que existem características da lógica campesina que são mantidas pelos agricultores familiares. Entre essas características, estão: as práticas sociais em que o interconhecimento é importante nas comunidades; a produção diversificada como prática pensada para autossubsistência e manutenção da autonomia relativa da unidade produtiva; a inter-relação nas formas de organização coletiva e de vida comunitária; a capacidade de adaptação e de transformação interna e externamente - a diferentes contextos sociais; as redes de relações sociais com modo de regulação e valores próprios; as estratégias de sobrevivência da família baseadas em seu patrimônio sociocultural e territorial para assegurar sua permanência no presente e no futuro.

Mendras (1976) ao tratar das transformações da economia camponesa frente à lógica moderna destaca como características das sociedades camponesas: a autonomia em face à sociedade global; a importância dos grupos domésticos e suas relações de ajuda mútua, de solidariedade e de trocas; a autarquia relativa do grupo doméstico; o interconhecimento e os mediadores entre a sociedade local e a sociedade global. Já o agricultor moderno tenderia a transforma-se em agente integrado, especializado em sua produção, ao fornecimento de matéria-prima, à produção em escala, à inserção nas cadeias longas de comercialização como foco no mercado global, ao cumprimento das normas e exigências externas (impostas pelo império agroalimentar), entre outras características.

O que se observa, mesmo sob diferentes interferências, é uma hibridez, uma continuidade entre tais aspectos na composição do que se define como agricultura familiar. Princípios camponeses (como interconhecimento, mediadores, produção para consumo próprio e da unidade produtiva, diversificação da produção, etc.) fazem parte da dinâmica sociocultural dos agricultores familiares como elementos

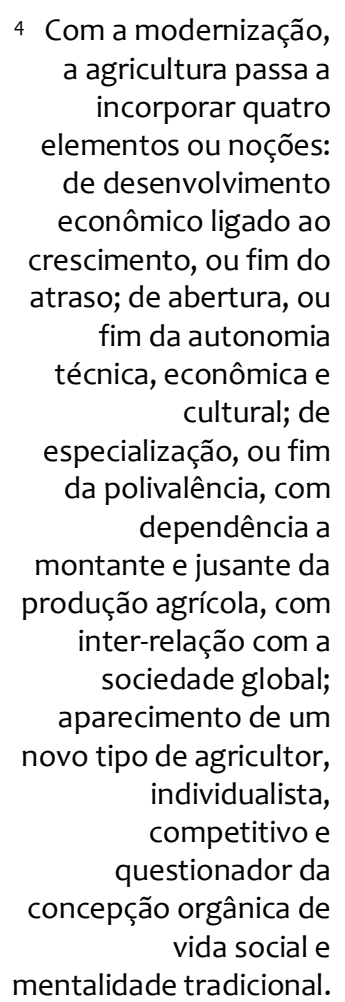


importantes na definição e articulação para solução de seus problemas, ao mesmo tempo que aderem em parte a aspectos da modernização, como a inserção em diferentes mercados, produção para cadeias longas, adequação às exigências externas, entre outras. De acordo com Wanderley (1996) e Abramovay (2007), a racionalidade da organização familiar se ampara na capacidade de adequação das estratégias de sobrevivência à conjuntura social, econômica e ambiental em que se desenvolve.

A agricultura de base familiar articula diferentes estratégias de sobrevivência. O que ajuda a compreender a forma imbricada de organização e modo de vida e das atividades no espaço de atuação destes agricultores. Dessa forma, a capacidade de adaptação das relações produtiva dos agricultores familiares é importante como estratégia na busca de soluções que ofereçam níveis satisfatórios de qualidade de vida (PLOEG, 2008).

Nesse sentido, a conjuntura histórica que influenciou a dinâmica social atual dos agricultores familiares remete à reflexão de quais são as estratégias, que mesmo sob a influência da modernidade e modernização, estão imbricadas no cotidiano e nas práticas socioeconômicas destes agricultores.

\section{Possibilidades nos mercados de proximidade: as feiras-livres}

Mesmo sob a hegemonia de mercado com normatizações oriundas da lógica da modernização e das pressões dos impérios agroalimentares globalizados, destaca-se que não existe apenas uma forma de mercado. Portanto, é possível afirmar que existe uma diversidade de "mercados" em constante transformação, imersos em peculiaridades culturais de cada lugar e nas capacidades de ação de seus agentes, ou seja, existe uma dinâmica de "mercados" construídos socialmente (CALLON, 2004; PLOEG, 2011; SABOURIN, 2011a).

Conforme Callon (2004, p. 75) o mercado pode ser entendido como "uma construção e reconstrução permanente, é uma construção coletiva que supõe negociações, interações e aprendizados." O contato direto, nesse caso, permite que ocorram negociações e que redes sociais se formem num processo coletivo, com margens de manobra e espaços estratégicos alternativos à lógica de mercado mundial e da adaptação à competição econômica, decorrentes da lógica da modernização. Ou seja, é uma construção social resultante da aprendizagem coletiva envolvendo uma rede de atores em que o universo de trocas e negociações é repleto de ideias, vontades e saberes.

Um mecanismo chave nos mercado de proximidades entre os envolvidos é o desenvolvimento do processo de reconhecimento dos valores (imaterial) que extrapolam os aspectos materiais e, desta forma, oportunizam uma dinâmica de relações de reciprocidade. Segundo Sabourin (2008; 2011b), os conhecimentos, as trocas de informações, de saberes, as amizades, a confiança, a maior equidade nas relações face a face permitem que valores éticos, espirituais e afetivos se misturem.

A diversidade de valores e saberes trocados vinculados aos aspectos sociais, culturais e econômicos, coloca em perspectiva o modo de vida dos agricultores familiares. Conforme Ploeg (2008), os circuitos curtos entre produção e consumo tem grande importância no fomento e construção social de economias locais e 
podem contribuir para os segmentos sociais que historicamente são marginalizados e excluídos pela lógica da modernização.

Nesses mercados, há exigências de valorização de outras dimensões do território que não somente a econômica. O grande diferencial nas cadeias curtas de comercialização é a possibilidade de alianças, de construção de mercados por meio de grupos organizados com o mesmo objetivo, corroborando com o "poder de agencia”, evidenciado por Giddens (1991), que pode conformar as estruturas locais.

Os mercados locais, pelo conjunto de peculiaridades e pela oportunidade de construção participativa, acabam funcionando como espaços de persistência de estilos de vida em que atributos do que é tradicional e do que é moderno estão imbricados. Segundo Corona (2006), os modos de vida dos agricultores familiares levam em conta estratégias que asseguram a reprodução da família e de seus estabelecimentos de forma que, mesmo sob exigências externas, há uma hibridez na dinâmica entre o que é moderno e o que é tradicional.

Os mercados de proximidade, com a valorização de produtos e serviços atrelados aos estilos de vida da agricultura familiar, impactaram positivamente estes agricultores. Isso porque o modelo baseado na extensão como difusão tecnológica e da pesquisa voltada aos produtos da modernização da agricultura (em especial o binômio soja/trigo) foi perdendo visibilidade e apoio estatal durante a década de 1980 no Brasil. Nos anos 1990, a extensão e a pesquisa estatais passaram a ser tratadas com maior afinco, pois houve uma mudança estrutural no foco de parte das empresas estatais. Constatava-se que a extensão rural com o objetivo de difundir a modernização da agricultura brasileira esgotava-se (FAO/INCRA, 1994), por um lado, pela falta de recursos financeiros para manter a propagação de pacotes tecnológicos, por outro, pela permanência da agricultura familiar muito fragilizada durante o processo de modernização. A resistência dessa parcela da população rural passou a ser o foco de parte da extensão rural brasileira.

Neste sentido, como ressalta Mior (2003, p.95), os agentes ligados à agricultura familiar passaram a incentivar "estratégias mais autônoma de agroindustrialização". Entre essas estratégias, ressaltava-se o incremento da diversificação produtiva, não apenas para consumo dentro da unidade produtiva, mas para a inserção mercantil sem atravessadores e a transformação de matériaprima em produtos processados, entre outras, o que, de certa forma, proporcionou a melhoria do bem-estar social, da qualidade de vida e a manutenção do modo de vida desses agricultores.

Nesse contexto, as feiras-livres, como um modo de comercialização que possibilita e facilita os contatos e a formação de redes sociais, passaram a ser uma entre as diferentes modalidades de inserção mercantil, incentivada pela "extensão rural”, que ganharam força, a partir da década de 1990, em diferentes localidades onde a agricultura familiar se fazia presente. Conforme Pirenne (1973), foi o aumento do volume de produção agrícola que possibilitou a reunião de agricultores com o mesmo objetivo, com poder de troca de mercadorias e, principalmente, de alimentos, num mesmo local, o que se denominou "feiras". 
Historicamente, o surgimento das feiras-livres é "atrelado ao aparecimento dos primeiros burgos e a intensificação das trocas comerciais" (ANJOS; GODOY e CALDAS, 2005, p.16) envolvendo os camponeses, artesãos e comerciantes. Assim, sua origem permeia a historia do campesinato que se insere no contexto de trocas, de compra e venda, no intuito de tornar seus produtos e serviços dotados de valor a ser intercambiado e disponibilizado para o consumo nas sociedades mercantis.

Essa origem foi se modificando ao longo do tempo, pois a modernização da agricultura5, voltada para o mercado, com os atributos baseados na tecnociência, na impessoalidade e entendido como mercado autorregulado (CALLON, 2004), tenderia a eliminar os processos de trocas pré-capitalistas, da mesma forma que o campesinato. Essa visão linear dos mercados e do processo de mudança social ignora, de certo modo, a busca de alternativas às consequências da modernização, pelos agricultores familiares, o que acabou revelando-se na opção pelas feiras-livres.

No Brasil, as feiras-livres são oriundas desse intercâmbio comercial presente no processo de transformação do modo de vida do campesinato, no contexto das consequências da modernização da agricultura. Segundo Sacco dos Anjos (2003), as unidades familiares têm como características a adequação de suas estratégias buscando a ocupação da mão de obra familiar, o aumento da renda total, assim como a diversificação e o uso dos recursos naturais e produtivos disponíveis.

Um importante marco no quadro social e político que reconhece a luta pela permanência da agricultura familiar brasileira foi o lançamento do Programa Nacional de Fortalecimento da Agricultura Familiar-PRONAF, no ano de 1996 (BIANCHINI, 2015). Entre os objetivos do PRONAF, cita-se a melhoria das condições e o aumento da capacidade produtiva, a geração de empregos e de renda e a melhoria da qualidade de vida, com foco no fortalecimento e a valorização dos agricultores familiares.

Assim, as feiras-livres passam a ser uma, entre as diferentes formas de organização econômica e social, que se constitui como estratégia de resistência, de alternativa aos agricultores familiares, na perspectiva de desenvolvimento local. Logo, vislumbra-se que, para superar as dificuldades postas pelo modelo de mercado hegemônico, as possibilidades de contato entre consumidor e agricultores fomentam relações tanto mercantis como socioculturais, que favorecem a manutenção de modos de vida peculiares aos agricultores familiares.

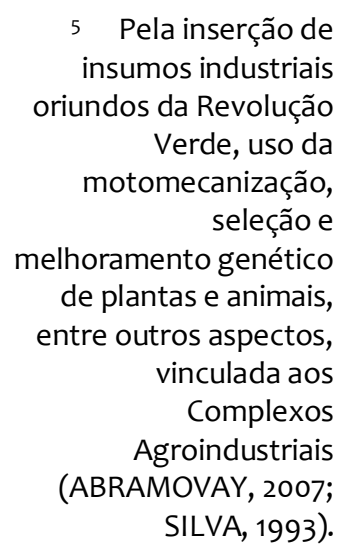

5 Pela inserção de insumos industriais oriundos da Revolução Verde, uso da motomecanização, seleção e melhoramento genético de plantas e animais, entre outros aspectos, vinculada aos Complexos Agroindustriais (ABRAMOVAY, 2007; SILVA, 1993). 


\section{O território, o locus da pesquisa e os aspectos metodológicos da investigação}

\subsection{Histórico, dados da agricultura familiar e da região de Chapecó - SC}

O município de Chapecó possuía, segundo Instituto Brasileiro de Geografia e Estatística-IBGE (2010), uma população estimada em 183.530 mil habitantes e está localizado na região oeste do Estado de Santa Catarina, com área de 626,057 km². Ver Figura 1.

Figura 1. Localização do Município de Chapecó-SC

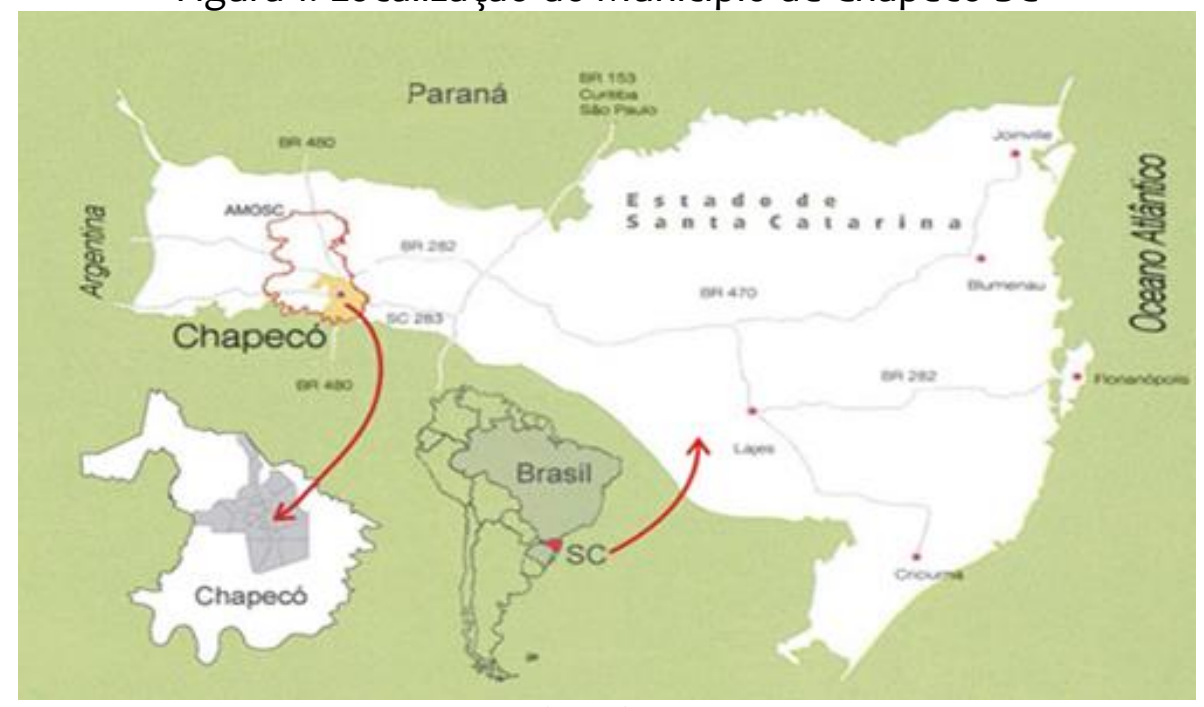

Fonte: Adaptado de Reche \& Sugai (2008)

As primeiras ocupações da atual região oeste do Estado de Santa Catarina, onde se localiza o Município de Chapecó, foi por povos indígenas Kaingang e Guaranis que habitaram diferentes territórios dos atuais estados do Sul do País (VEIGA, 2006). Por volta do século XIX, o povo luso-brasileiro se miscigenou com índios e escravos dando origem aos caboclos. Essa miscigenação influenciou na caracterização religiosa e no modo de vida nas unidades produtivas, com foco na subsistência e na extração de madeira e erva-mate (CHAPECÓ, 2015).

Posteriormente, a região oeste teve forte influência das empresas colonizadoras que organizaram e trouxeram descendentes de origem europeia, oriundas, principalmente, do Estado do Rio Grande do Sul, e que tiveram no núcleo familiar a maior parte da mão de obra para a produção agrícola (TESTA et al., 2003). Foi essa predominância da agricultura de base familiar que possibilitou a mudança para o sistema de integração entre indústrias e agricultores desde a década de 1940.

Nessa região, o processo de modernização dentro da agricultura familiar ocorreu por meio das integradoras (em especial dos setores que envolvem frigoríficos e processadores de carnes). Isso é, foram as agroindústrias que promoveram a inserção mercantil destes agricultores, neste caso, de forma indireta. Esse processo de modernização ocasionou mudanças significativas nos sistemas produtivos com características camponesas voltadas para a autossuficiência, por meio da utilização dos pacotes tecnológicos, das normas técnicas, da introdução do melhoramento genético, do uso de insumos e equipamentos agrícolas. Essas mudanças foram acompanhadas de exigências técnicas que se tornaram ao longo 
do tempo, fatores importantes de exclusão de inúmeras famílias do modelo de integração (MIOR, 2003).

O foco de trabalho da extensão rural nos anos 1990 passou a ter como público alvo os agricultores familiares que não participaram do processo de integração com os complexos industriais excluídos do processo pelas exigências de incremento tecnológico e de produtividade, assim como aqueles que, mesmo integrados, procuraram novas estratégias de trabalho e busca de maior autonomia. O foco principal da extensão remete aos mecanismos de diversificação de mercados, do contato direto entre produtores e consumidores e de melhoria da qualidade de vida dos agricultores familiares.

E nesse contexto que, na década de 1990, as feiras-livres do Município de Chapecó, denominadas de "Feiras de Produtos Coloniais e Agroecológicos de Chapecó", trouxeram uma nova perspectiva de atividade para os agricultores familiares. Segundo dados da SEDEMA, que administra o programa de feiras-livres, em 1991, havia oito famílias de agricultores que ampliaram suas atividades passando não apenas a produzir, mas a se inserirem no mercado de venda direta ao consumidor.

Quadro 1. $\mathrm{N}^{\circ}$ imóveis rurais, $\mathrm{n}^{\circ}$ de blocos de produtor rural e $\mathrm{n}^{\circ}$ de declarações de aptidão ao Programa Nacional de Fortalecimento da Agricultura Familiar de

Chapecó no ano de 2015

\begin{tabular}{|ll|}
\hline Descrição & Número \\
\hline Blocos de produtor rural & 1970 \\
No de blocos de produtor ativos / propriedades com até 80 ha & 1922 \\
No de blocos / propriedades com mais de 80 ha & 45 \\
Declarações de aptidão ao PRONAF-DAP & 1264 \\
\hline
\end{tabular}

Fonte: Dados da Prefeitura Municipal de Chapecó (2015).

O Município de Chapecó (CHAPECÓ, 2015) é predominantemente urbano e tem na indústria, no comércio e nos serviços aproximadamente $95 \%$ das receitas econômicas. No setor agrícola, no ano de 2015, predominou a produção de ovos (comercial e fértil), seguida de produção suína, soja, frangos, leite e milho. Segundo o Quadro 1 acima, elaborado com base nos dados da SEDEMA (2015), existem 1970 blocos de produtores rurais ativos em Chapecó. Desses, 1264 (64\% em relação ao total de blocos de produtores) possuem declarações de aptidão ao PRONAF- DAP, assim como a maior parte dos blocos de produtor rural (1922) está vinculado a propriedades que possuem menos de 80 ha, mostrando que a agricultura familiar tem grande expressão no contexto local, sendo inclusive foco para os programas de extensão rural.

\subsection{Metodologia}

A partir do objetivo estabelecido para a pesquisa, esta seção apresenta como foi realizada a pesquisa, que conteve duas etapas importantes. A primeira etapa buscou levantar dados gerais sobre as características das famílias feirantes de Chapecó, por meio do cadastro das famílias de feirantes que trabalham nas dez feiras-livres de Chapecó-SC. De posse dessas informações, optou-se pela entrevista 
com uso de um formulário semiestruturado, aplicado a todas as 63 famílias responsáveis pelas 104 bancas de comercialização distribuídas nos dez pontos de feira-livre $\mathrm{O}$ objetivo, nesse momento, era, além de conhecer as famílias feirantes, selecionar as famílias que se enquadrassem em dois critérios: as que eram agricultores familiares e que residiam no Município de Chapecó.

Essa etapa foi realizada por meio de entrevistas, entre abril e maio de 2015, sendo que os resultados possibilitaram caracterizar o perfil socioeconômico das famílias e de suas atividades. Vale ressaltar que a entrevista é entendida como uma importante ferramenta da pesquisa social (RICHARDSON, 2008), que requer a presença dos interlocutores face a face, permitindo o diálogo. Como resultado dessas entrevistas, verificou-se que, das 63 famílias de feirantes que trabalham nos dez pontos de feiras-livres, 39 se enquadram nos conceitos, princípios e legislação que se referem à categoria de agricultores familiares e que residem no Município de Chapecó.

Para atender aos objetivos da pesquisa, levando-se em consideração o tempo restrito e os recursos disponíveis, houve a necessidade de escolha de quais feiras-livres fariam parte da segunda etapa, destinada a entrevistas em maior profundidade, com base em roteiro de questões abertas e outras semiestruturadas. Para essa escolha, o critério de seleção foi privilegiar aquelas que possuíam maior representatividade de agricultores familiares feirantes de Chapecó. Dessa forma, foram escolhidas as duas feiras-livres centrais como local para a segunda fase, a de entrevistas pela maior abrangência de famílias de agricultores familiares.

Nessa etapa, foram entrevistadas 28 famílias com o foco das perguntas voltado à compreensão de características atreladas às práticas de mercados, tais como: a renda bruta da atividade de feira-livre aferida por eles, a participação das familiais na construção das feiras-livres, ambiente de trocas, de relações sociais e as motivações presentes para ingresso, investimento e permanência nas feiras-livres.

Para tratar das informações dos perfis socioeconômicos e das atividades desenvolvidas, foram utilizados quadros e gráficos que permitissem expor os dados gerais. Concomitantemente, fora utilizada a análise de conteúdo (BARDIN, 2009) para categorizar as respostas dos entrevistados, que permitisse descrever, a partir das falas dos feirantes na fase de entrevistas, aquilo que expressasse as estratégias de inserção e permanência nesse mercado de proximidade denominado feira-livre, destacando as principais ideias que demonstram as relações sociais e os atributos relevantes para os entrevistados.

\section{Os feirantes agricultores familiares de Chapecó}

Neste item, são apresentadas as características sociais, econômicas e culturais das 28 famílias de agricultores familiares que participam das duas feiraslivres da região central de Chapecó. Entre essas características, foram abordadas: a origem étnica dos ascendentes, a faixa etária, a sucessão familiar nas atividades de trabalho, as instituições presentes na vida comunitária local, os tipos de atividades desenvolvidas pelos feirantes e a diversidade de produtos ofertados nas feiras, a porcentagem da renda bruta proveniente das feiras-livres e o envolvimento histórico das famílias com as feiras-livres. 
Como visto acima, o Município de Chapecó, assim como grande parte dos municípios do entorno, teve, em seu processo de formação histórica, a presença de povos indígenas, caboclos e a influência dos processos de colonização com predomínio de descendentes de imigrantes oriundos da Itália e da Alemanha (VEIGA, 2006, PEREIRA \& FREDDO, 2007). Verifica-se que essa situação está presente nas respostas dos feirantes, pois a mais citada foi a de origem italiana e a segunda, a "brasileira" que corresponde à miscigenação, em geral de caboclos, na região. As outras respostas dos feirantes são a de origem italiana/alemã, brasileira/italiana/alemã/ e portuguesa/espanhola, como mostra o Gráfico 1.

Gráfico 1. Origem dos ascendentes dos feirantes responsáveis pelas bancas

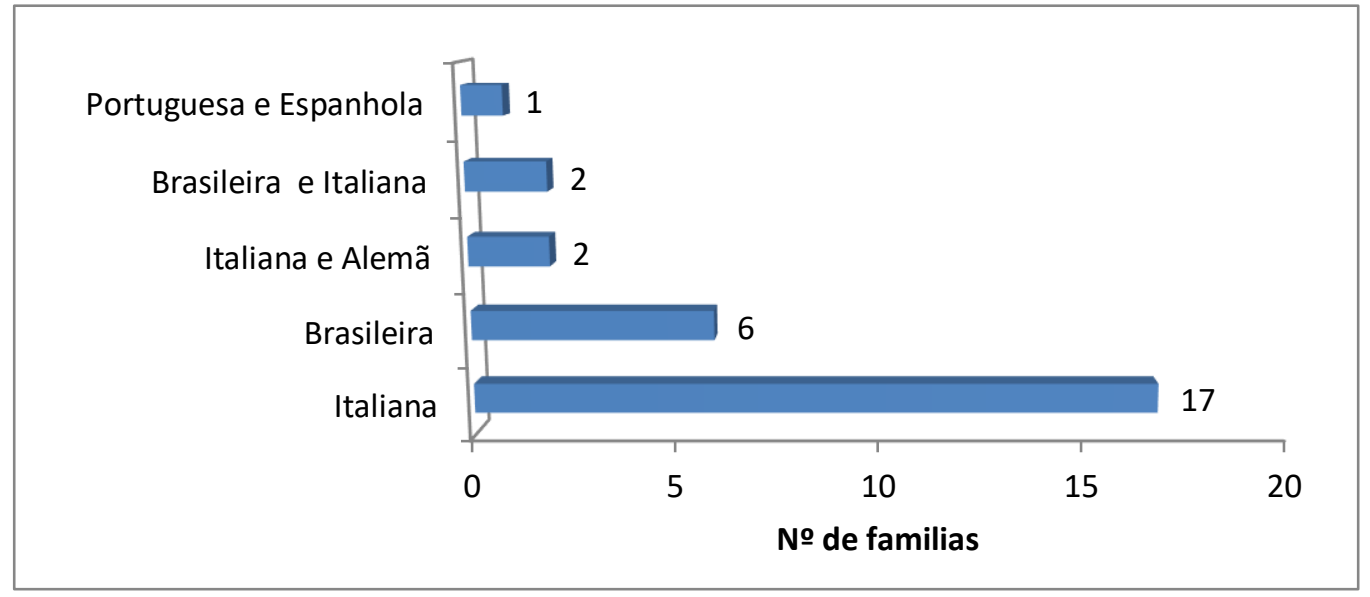

Fonte: Elaborado a partir dos dados da pesquisa. Chapecó, SC. Mar-2014/Dez-2015.

Uma das preocupações em relação à categoria de agricultores familiares que aparece nas respostas dos feirantes, refere-se à sucessão das unidades produtivas e o envelhecimento desta população, tornando-se um dos desafios para a permanência da agricultura familiar. No caso dos feirantes de Chapecó, a grande maioria dos responsáveis pelas bancas de feiras-livres possui mais de 50 anos. Conforme mostra o Gráfico 2, nove feirantes possuem menos de 50 anos e 19 estão na faixa etária superior a esta idade. Uma possível explicação é que as feiras-livres centrais são as mais antigas da cidade e são poucas as famílias que ingressaram recentemente, fato que pode estar relacionado à faixa etária dos responsáveis pelas bancas das feiras-livres. 
Gráfico 2. Faixa etária dos feirantes responsáveis pelas bancas

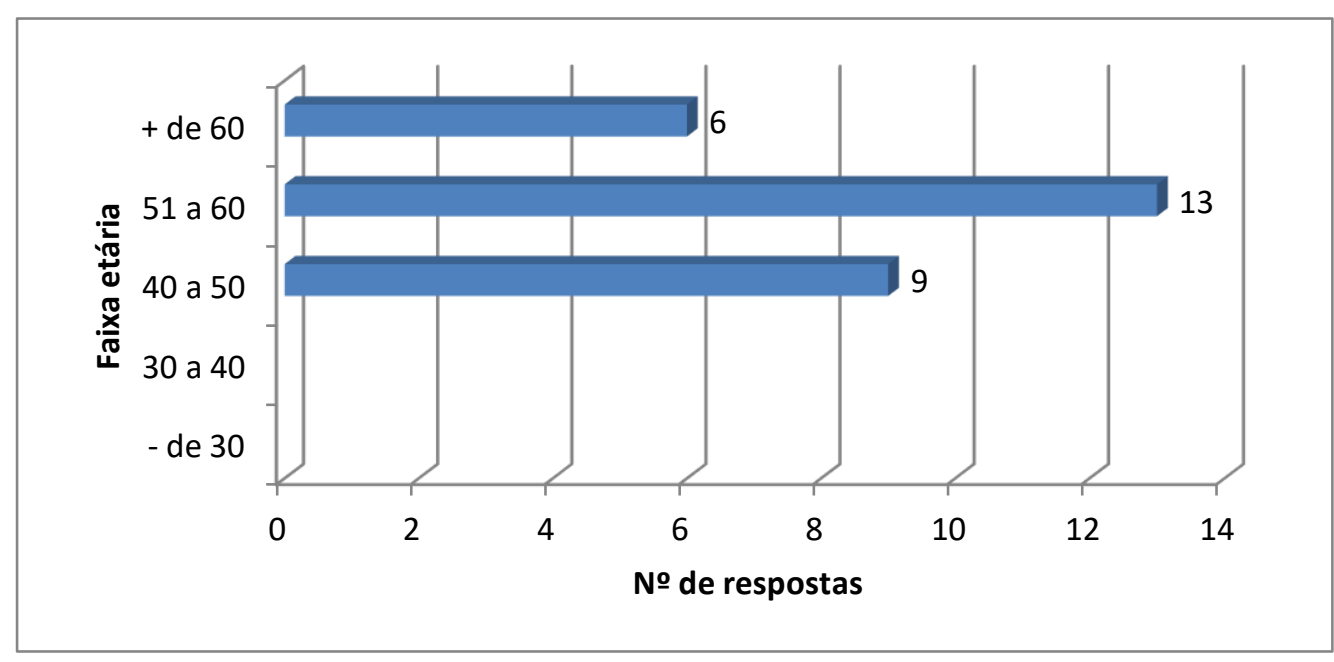

Fonte: Elaborado a partir dos dados da pesquisa. Chapecó, SC. Mar-2014/Dez-2015.

No entanto, esse fato implica em mudanças no planejamento das propriedades e, no caso dos agricultores feirantes, na continuidade ou não das atividades junto às feiras-livre. Verifica-se, no Gráfico 3, que 11 famílias de feirantes possuem sucessores já trabalhando na atividade produtiva e de comercialização e 17 famílias não possuem sucessores na atividade. Mesmo sendo significativo o número das famílias com sucessores na atividade, a maioria não os possui, o que remete a pensar tanto no risco da continuidade das unidades produtivas familiares como da feira-livre. Esses dados corroboram os estudos de Abramovay et al. (2001), que já apontavam vazios demográficos na região oeste de Santa Catariana.

\section{Gráfico 3 - Famílias com ou sem sucessores de suas atividades}

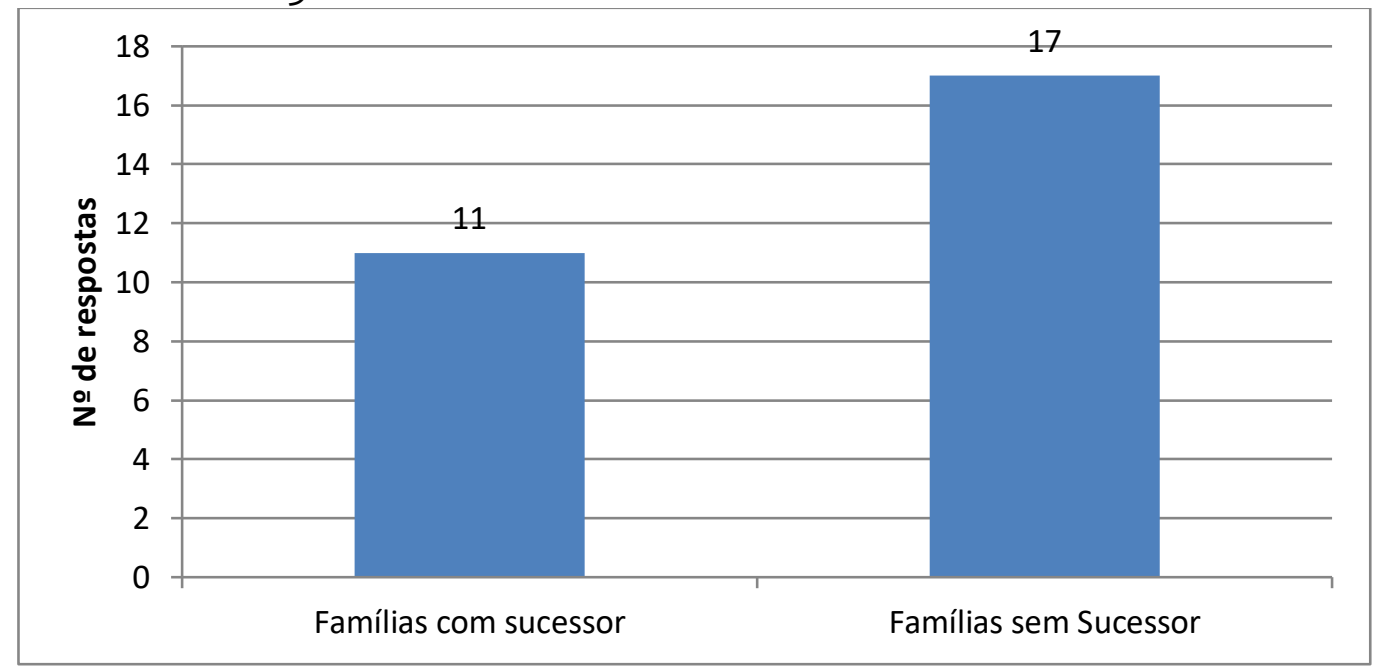

Fonte: Elaborado a partir dos dados da pesquisa. Chapecó, SC. Mar-2014/Dez-2015.

Entre as práticas sociais comuns, destaca-se a participação junto às instituições e entidades que envolvem a vida profissional e comunitária (Ver Quadro 2). Todas as famílias de agricultores, das duas feiras centrais, relataram que participam das atividades de igreja; quatorze famílias responderam que participam da Associação de Produtores Feirantes de Chapecó - APROFEC; nove participam do 
conselho comunitário de onde residem. Ressalta-se que estas práticas sociais comunitárias de interações face a face e de interconhecimento são tradicionalmente características da lógica camponesa (MENDRAS, 1976; WANDERLEY, 1996) e apresentam-se presentes na dinâmica dos feirantes agricultores familiares entrevistados. Esse tipo de prática social remete à corresponsabilidade de práticas coletivas que organizam a vida e o cotidiano da comunidade.

Quadro 2.Instituições comunitárias que os agricultores familiares participam

\begin{tabular}{|l|c|c|}
\hline \multicolumn{1}{|c|}{ Tipo de instituição } & Denominação & $\mathbf{N}^{\circ}$ de respostas \\
\hline Igrejas & Católica & 26 \\
& Evangélica & 1 \\
\hline Associações & Espírita & 1 \\
\hline Conselhos & APROFEC & 14 \\
\hline Sindicatos & Conselho Comunitário & 9 \\
\hline Partidos políticos & Sindicato dos Trabalhadores Rurais & 18 \\
\hline Cooperativas & Partido dos Trabalhadores & 2 \\
& Cooper Familiar & 9 \\
& Cooper Familiar/Cresol & 1 \\
& Cooper Familiar/Alfa & 2 \\
& Cooper Familiar/Alfa/Cresol & 2 \\
& Cooper Alfa & 4 \\
\hline
\end{tabular}

Fonte: Elaborado a partir dos dados da pesquisa. Chapecó, SC. Mar-2014/Dez-2015.

De forma expressiva, há a inserção deles nas cooperativas que, em geral, tem em sua lógica a possibilidade de inserção em mercados, além da interação social, pois, como mostra o Quadro 2, vinte feirantes participam de cooperativas da região. Entre as citadas, estão a Cooperativa Alternativa da Agricultura FamiliarCooper Familiar, o Sistema de Cooperativas de Crédito Rural com Interação Solidária-CRESOL e a Cooperativa Agroindustrial Alfa-Cooper Alfa. Também de forma expressiva, dezoito famílias feirantes participam do Sindicato de Trabalhadores Rurais e duas evolvem-se politicamente no Partido dos Trabalhadores.

Entre as atividades desenvolvidas pelas famílias de agricultores, observa-se quatro grandes áreas de atuação com a finalidade comercial. Entre essas áreas, foram catalogados produtos alimentícios de origem animal-POA, produtos alimentícios de origem vegetal-POV, produtos ornamentais de origem vegetal-ORN e produtos alimentícios panificados-PAN, conforme descrito no Gráfico 4. 
Gráfico 4. Tipos de atividades desenvolvidas, $\mathrm{n}^{\circ}$ de agricultores familiares em cada atividade, $\mathrm{n}^{\circ}$ de bancas de agricultores familiares de Chapecó nas duas feiras-livres centrais

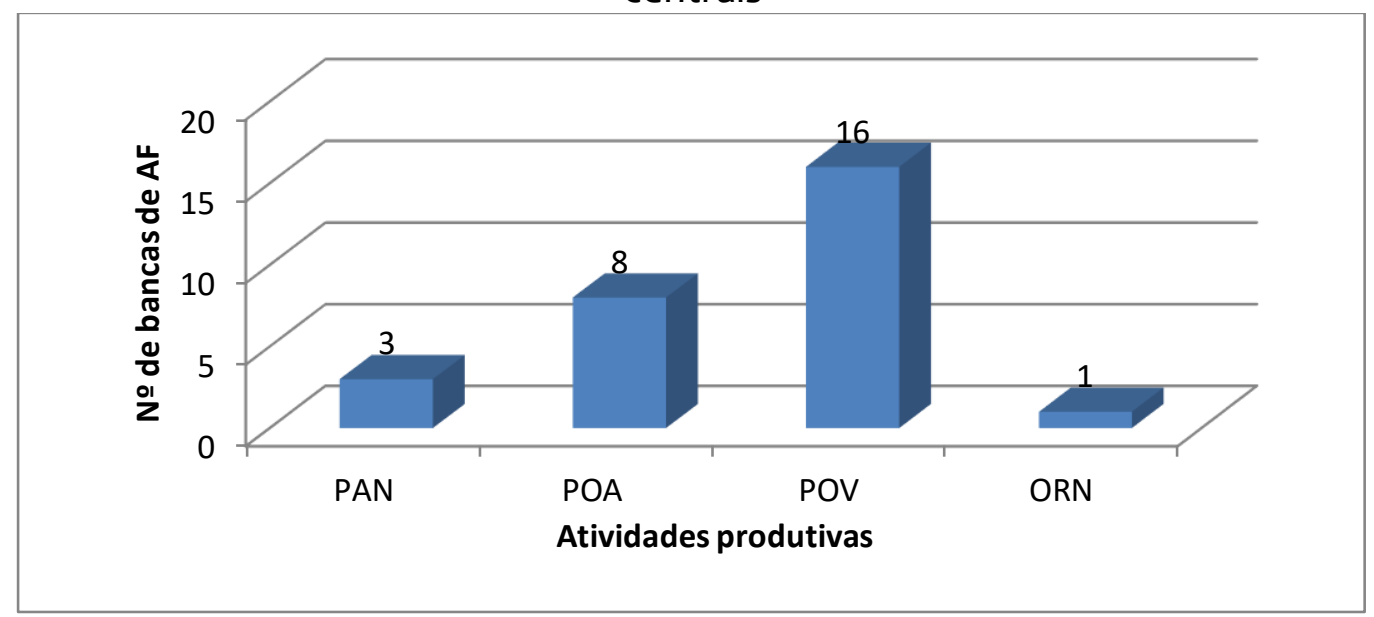

Fonte: Elaborado a partir dos dados da pesquisa. Chapecó, SC. Mar-2014/Dez-2015.

Nas duas feiras-livres centrais, são três as famílias de agricultores familiares feirantes trabalhando com PAN, dezesseis com POV, oito com POA e uma com ORN. Pode-se observar que há importante diversidade de produtos ofertados pelos feirantes em praticamente todas as bancas, o que corrobora diferentes autores, entre eles Wanderley (1996), Mior (2003), Abramovay (2007) e Ploeg (2011), os quais ressaltam em seus trabalhos a capacidade de adaptação e autonomia atreladas à lógica de diversificação produtiva nas unidades de produção da agricultura familiar.

A renda bruta da atividade de feira-livre auferida pelos agricultores familiares, nos últimos 12 meses, a contar da data de entrevista. Demonstra que comercialização nessas feiras contribui significativamente para o sustento familiar. Conforme dados expostos no Gráfico 5, verifica-se que para a maioria das famílias, esse mercado de proximidade afere mais de $50 \%$ em relação a sua principal fonte de renda. A renda é uma das necessidades para apropriação da autonomia socioeconômica das famílias que, neste caso, foi oportunizada por meio da inserção nesta cadeia curta de comercialização.

Gráfico 5. Porcentagem da renda bruta familiar proveniente da atividade de feiralivre

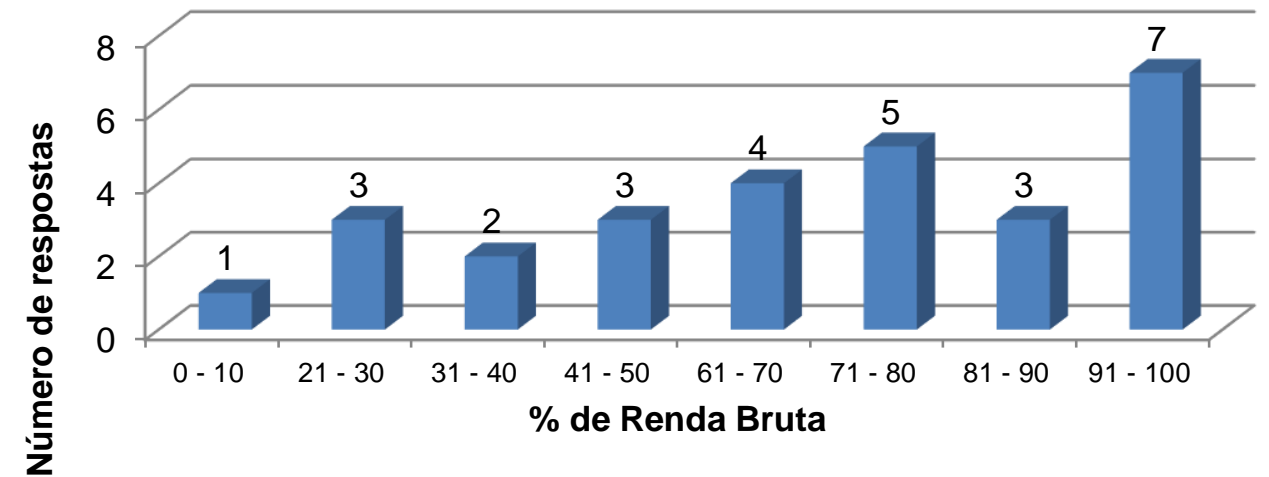

Fonte: Elaborado a partir dos dados da pesquisa. Chapecó, SC. Mar-2014/Dez-2015. 
Percebe-se nas falas dos feirantes agricultores familiares que sua inserção nos mecanismos de comercialização, com contato face a face, é importante para superar a racionalidade do mercado hegemônico, caracterizado pelo acúmulo de capital e de relações impessoais, sem trocas sociais. Conforme a declaração do próprio feirante AT abaixo, a atividade de feira-livre, que poderia ser apenas uma alternativa econômica, trouxe uma nova perspectiva para a família, a ponto de sentirem-se comprometidos por fazerem parte da história de construção deste mercado, denominado feira de agricultores coloniais e agroecológicos de Chapecó:

na feira, comprando direto do produtor eles sentem mais confiança em comprar nossos produtos, é isso que eu sinto. Os clientes buscam qualidade. $O$ contato também que eles têm com quem produz. Em outros mercados eu não ganho o valor que meu produto tem. A feira é uma tradição de família, temos uma obrigação com a feira-livre. (Entrevista com o feirante AT).

Verifica-se que a feira-livre é um ambiente que propicia a troca de experiências sobre diferentes formas de produção e trabalho, com vivências sociais que hibridizam características tradicionais com as mudanças decorrentes da modernidade e do mercado hegemônico. Essa continuidade de práticas socialmente constituídas, conforme destacado por Giddens (1991), possibilita a construção, no espaço e no tempo, de condutas compartilhadas, conhecidas e aceitas entre os agentes envolvidos. Isso pode ser verificado na fala do feirante OM:

temos trocas de experiências passadas. Têm muitas pessoas que vieram do interior, os clientes pedem variedades de figo que eles conheciam no interior, temos a raiz aqui na feira [...] As experiências de vidas, aqui encontramos pessoas com os mesmos valores. (Entrevista com o feirante $\mathrm{OM})$.

Historicamente, as feiras-livres de Chapecó foram resultado da construção com base em relações sociais entre as famílias agricultoras, com apoio de técnicos. Quando são comparadas as motivações para os agricultores ingressarem com as motivações para permanecerem na atividade de feirante, levando em conta os atributos considerados importantes no contato entre agricultores e consumidores, visualizaram-se algumas mudanças importantes.

Entre os atributos referenciados nas respostas (Ver Gráfico 6), como motivações de inserção na feira-livre destaca-se: o sustento (24 citações), o incentivo de técnicos da Prefeitura Municipal (23 citações), a comercialização direta (21 citações), o incentivo de famílias que já estavam inseridas nessas atividades (20 citações), por ser a única alternativa (dez citações) e de modo muito restrito a autonomia (uma citação), o que denota a forte influência externa nas decisões do grupo.

Entre os atributos referenciados nas respostas (Ver Gráfico 6) como motivações que os conduzem a permanecer e investir na feira-livre situam-se no mesmo nível de importância a comercialização direta (vinte e oito citações), o sustento (27 citações), a autonomia ( 27 citações), o contato face a face (27 citações), as amizades (24 citações) e, por último, como única alternativa (nove citações). 
Gráfico 6. Razões para inserção/permanência e retribuição dos clientes na atividade de feira-livre

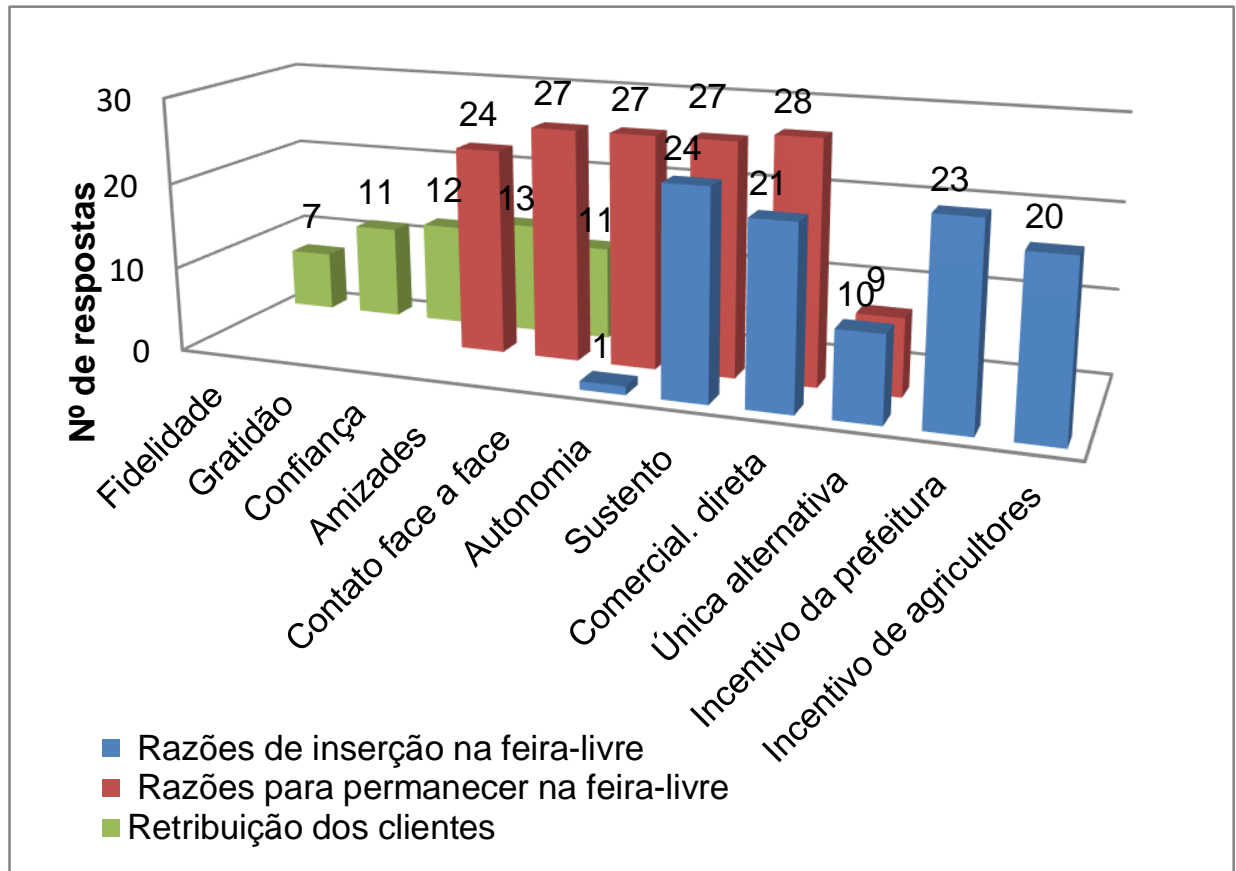

Fonte: Elaborado a partir dos dados da pesquisa. Chapecó, SC. Mar-2014/Dez-2015.

Diante desses dados, é possível destacar que eles corroboram com a compreensão de Callon (2004) de que esse tipo de mercado é uma prática social construída de forma coletiva, envolvendo instituições (prefeitura municipal) e os agricultores familiares. Essa forma de comercialização construída de forma conjunta, está vinculada à lógica de vida comunitária dos agricultores, o que remete às características camponesas, como o interconhecimento (MENDRAS, 1976), o caráter familiar ${ }^{6}$ (CHAYANOV, 1974) e o poder de agenciamento (GIDDENS, 1991).

Como se observa no Gráfico 6, no momento da decisão sobre o ingresso nas feiras-livres, a autonomia não foi um aspecto relevante para a grande maioria das famílias (uma família), no entanto, passou a ser um dos mais importantes para permanecer na atividade ( 27 famílias). Foi na trajetória da feira que essas famílias agricultoras perceberam que a autonomia, uma característica do modo de organização das famílias camponesas anterior à modernização, tornasse-se um atributo de enfrentamento e relativa independência em relação à lógica de integração produtiva aos complexos agroindustriais, que prevalecem no município. Essa é a autonomia referenciada por Ploeg (2008), pois, mesmo convivendo com as pressões das empresas alimentares globalizadas, permanecem aspectos da condição camponesa.

Além da autonomia, outras características podem ser observadas no Gráfico 6. O "sustento" foi um aspecto relevante
6 Uma das noções que permite ampliar a noção de família nuclear moderna é a proposta por Chayanov, quando diz que "família inclui as pessoas que comem sempre na mesma mesa ou que comeram da mesma panela" (CHAYANOV, 1974, p.48). 
tanto para aderir como para manter-se na feira, o que pode ser entendido como o equilíbrio entre o trabalho familiar e o atendimento de suas necessidades de consumo (CHAYANOV, 1974). Como lembra Wanderley (1999), é nas unidades de produção, onde os agricultores familiares assumem o trabalho necessário, é que a estrutura interna da família (número e idade de seus membros) e suas necessidades assumem papel relevante para sua dinâmica de funcionamento. Ou seja, uma vez que o eixo é a satisfação das suas necessidades, a autonomia torna-se um elemento fundamental na organização social dessas famílias, pois as decisões levam em conta não apenas as demandas do mercado, mas o bem-estar da família.

Em seguida, destaca-se o contato face a face que constrói relações de confiança, ou de copresença, o que remete a informações acessíveis que circulam entre feirantes agricultores e consumidores, não intermediadas pelas geradas abstratamente pelos sistemas peritos (GIDDENS, 1991). A busca pela satisfação das demandas dos clientes, o respeito, a honra e o prestígio remetem à frequência das relações de trocas, uma vez que os produtos carregam a história familiar, a reciprocidade7 (MAUSS, 2013, SABOURIN, 2011b). Por fim, a importância das relações sociais, econômicas e culturais, que compartilham sentimentos, responsabilidades e valores, materiais e imateriais (SABOURIN, 2010, 2011b).

As afirmações acima corroboram os atributos citados, como retribuição dos clientes, as amizades (13 citações), a confiança (12 citações), a gratidão (11 citações), o contato face a face (11 citações) e a fidelidade (sete citações). Esse conjunto de valores sociais que acompanham os produtos e serviços dos agricultores converte-se em valores imateriais, valores que estruturam um estilo de vida em que o cotidiano de "fazer a feira" tem neste local a referencia de lugar e no contato face a face, a conexão de tempo e espaço referenciada por Giddens (1991).

Chayanov (1974) chama a atenção para esse conjunto de características internas: a organização das famílias de agricultores que acabam sendo importantes na configuração da estrutura, não apenas de valores econômicos, mas simbólicos e que estão envolvidas no sistema de economia local, neste caso, nas feiras-livres.
7 Entende-se

reciprocidade como "sinônimo de solidariedade (dependência mútua, fato de ser solidário) ou de mutualidade" (SABOURIN, 2011b, p.10).

$\mathrm{Na}$ evolução da unidade econômica que descrevemos, devemos finalmente assinalar as mudanças que, graças socialização dos vínculos individuais no plano organizativo, devem completar-se em profundidade dentro da unidade de produção familiar pelo mecanismo do equilíbrio interno e com seu processo característico de formação do capital. (CHAYANOV, 1974, p. 319). 
Uma demonstração recorrente de reciprocidade no decorrer das feiras-livres foi a troca de amabilidades entre as/os atendentes e seus/suas clientes ao se cumprimentarem com abraços, ao se chamarem pelo nome e ao dedicarem tempo de suas vidas para trocar brincadeiras e histórias de vida. Essa é uma demonstração de que há envolvimentos pessoais e são firmados vínculos entre as partes. Os resultados de cada ação são importantes para a configuração do ambiente de trabalho. Nesse caso, os resultados são percebidos na formação de laços de sociabilidade identificados nas próprias palavras do entrevistado OM:

\begin{abstract}
a feira é bem gratificante. Meu pai sempre fala do prazer de conviver com as pessoas. Aqui acabamos cuidando um dos outros [...] Pelo bem-estar é muito diferente de outros mercados. Temos mais liberdade e o ambiente é mais rico (há diversidade cultural) [...] Há uma troca de confiança, os clientes confiam na gente e nós confiamos neles [...] Tem gente que entra aqui na banca para conversar e ficam mais de hora [...] A pessoa vai onde as pessoas te entendem, onde conversamos [...] Há gratificação. Aqui as pessoas dão valor ao que você faz, (nossa produção) é além do valor financeiro. (Entrevista com o feirante OM).
\end{abstract}

A complexidade das trocas que fundamentam valores imateriais entre os agentes envolvidos é permeada de simbologias e de valores, como a reciprocidade e a confiança. Percebe-se, nas falas dos feirantes, a importância atribuída a uma série de atributos, como as amizades, a troca de conversas e receitas, a simples valorização pela atividade de feirante no município pelos órgãos públicos, a construção de confiança oportunizada pelo convívio na feira-livre. Segundo Godoy (2005) a feira-livre é um espaço de comercialização e relações socioeconômicas em que os aspectos culturais e simbólicos ganham maior protagonismo.

\begin{abstract}
A amizade que temos com as pessoas, até quando caminhamos na cidade eles vem e nos chamam para conversar [...] Quando fizeram a filmagem aqui na feira e nos entrevistaram nós ganhamos muitos clientes, poxa nós nos sentimos tão valorizados. A prefeitura fez até um quadro de agradecimento pelo trabalho na feira [...] O cliente tem confiança na gente e pede se pode pagar na outra feira, ele confia na gente e agente também confia nele. (Entrevista com o feirante TP)
\end{abstract}

Com base nos resultados apresentados neste trabalho, pode-se observar que a prática da feira-livre pelos agricultores familiares de Chapecó, mesmo com influências externas, traz características da lógica de funcionamento das unidades familiares de produção na agricultura. São características próprias ao modo de vida desses agricultores, que remetem ao modo de vida camponês. Nesse caso, verificase que o sistema de valores, de simbologias, de confiança e de reciprocidade no funcionamento das feiras-livres remetem ao que Chayanov (1974) e Wanderley (1999) mostraram como sendo a lógica camponesa de maximização da felicidade e do bem-estar da família. Ou seja, o planejamento da organização interna envolvendo trabalho e consumo, é sempre visando atender ao grau de satisfação das necessidades momentâneas e futuras desta família. 
Assim, as influencias das leis gerais de reprodução do capital e as restrições que o sistema de normas estatais coloca para essa atividade (regras sanitárias, padrões de produção, etc) ${ }^{8}$ não anulam essa lógica de práticas e sociabilidades dos agricultores. Segundo Wanderley (1999, p.36) “mesmo estando integrada ao movimento geral de valorização do capital, a economia camponesa se reproduz sobre a base dos princípios gerais de seu funcionamento interno, nos termos apresentados por Chayanov". No entanto, vale destacar que eles não estão dissociados das pressões que o mercado hegemônico exerce sobre a agricultura familiar, nem das tensões no acesso às políticas públicas (PRONAF, por exemplo) e a extensão rural, haja vista que essas dependem de como os governos se posicionam frente à agricultura de base familiar.

\section{Considerações Finais}

O conjunto de informações apresentados neste estudo dão a dimensão da importância da feira-livre para além dos aspectos econômicos, com destaque privilegiado de atributos que coincidem com o modo de vida da agricultura familiar, como a busca pela autonomia, as relações de interconhecimento, a sociabilidade estendida aos consumidores, desaparecendo as influências externas às propriedades agrícolas.

O desafio do estudo almejou a pensar criticamente os processos de configuração deste ambiente mesmo sob a influência da lógica da modernidade. A rica diversidade do Brasil com inúmeros potenciais atrelados às peculiaridades culturais locais favorece as experiências de mercados locais e as práticas de construção social de mercados de proximidade. Dessa forma, esses modelos alternativos de inserção mercantil, frente às normas e regras definidas e coordenadas pelos impérios agroalimentares, trazem novas perspectivas de sustentabilidade social e econômica.

Pelos atributos evidenciados nas respostas dos feirantes, as feiras-livres afirmaram-se como espaços de interação social, cultural e cognitivo e não apenas como espaço de trocas materiais. Nesse sentido, pode-se afirmar que a dinâmica social de atuação sobre mercados locais, como as Feiras de Produtos Coloniais e Agroecológicos de Chapecó, mostra-se como uma estratégia que tem se destacado como espaço de continuidade e manutenção de aspectos da tradição destas famílias. Esse espaço contém adaptações a aspectos do modelo hegemônico de mercado, naquilo que possa garantir a permanência do modo de vidadas famílias.
8 Tema importante a ser tratado em outra oportunidade, dado o fato de não ter sido esse o foco da pesquisa. 
São essas particularidades do dia a dia das feiras-livres que movem a lógica da casa e das famílias destes agricultores e trazem, nas relações de confiança, de amizade, de contato face a face, a essência da dinâmica camponesa. São atributos que se mostram presentes e indissociáveis nas práticas desses agricultores que, basicamente, dirigem toda sua lógica para maximizar a felicidade e o bem-estar da família.

Frente ao contexto de interferências da lógica do mercado globalizado os estudos sobre as estratégias de acesso aos mercados, adotadas pelos agricultores familiares, são importantes para garantir a autonomia do seu modo de vida, assim como para o reconhecimento e valorização dos atributos que, na opinião destes, são relevantes para a continuidade e melhora da qualidade de vida em seu ambiente de atuação. Os estudos acerca das práticas de mercado adotadas pelos agricultores familiares são considerados de extrema importância para o entendimento da sua contribuição para a dimensão social e econômica dos agricultores.

\section{REFERÊNCIAS}

ABRAMOVAY, Ricardo. Paradigmas do Capitalismo Agrário em Questão. São Paulo: HUCITEC, 2007.

ABRAMOVAY, R. et. al. Agricultura familiar e sucessão profissional: novos desafios. In: XXXIX CONGRESSO BRASILEIRO DE ECONOMIA E SOCIOLOGIA RURAL. Anais... Recife, PE. 2001. CD-ROM

ALMEIDA, J. Da ideologia do progresso à ideia de desenvolvimento (rural) sustentável. In: ALMEIDA, J; NAVARRO, Z (orgs). Reconstruindo a agricultura: ideias na perspectiva do desenvolvimento rural sustentável. Porto Alegre: Editora da Universidade. 1998.

ANJOS, F.S. dos; GODOY, W.I.; CALDAS, N.V. As Feiras-livres de Pelotas sob o império da globalização: perspectivas e tendências. Pelotas: Ed. e Gráfica Universitária, 2005.

BARDIN, Laurence. Análise de Conteúdo. Lisboa, Portugal; Edições 70, LDA, 2009.

BECK, Ulrich. Sociedade de risco: rumo a uma outra modernidade. São Paulo: Editora 34, $1^{\circ}$ Ed. 2010.

BIANCHINI, Valter. Vinte Anos do PRONAF, 1995-2015: avanços e desafios. Brasília: SAF/MDA, 2015. 113 p. Disponível em:< http://www.mda.gov.br/ sitemda/sites/sitemda/files/ceazinepdf/PRONAF_20_ANOS_VALTER_BIANCHINI.pdf >. Acesso em: 20 jan. 2016.

CALLON, Michael. Por uma nova abordagem da ciência, inovação e do mercado. IN: PARENTE, A. (Org.) A trama da rede. Porto Alegre: Sulina, p.64-79, 2004. 
CORONA, Hieda M.P. A Reprodução social da agricultura familiar na Região Metropolitana de Curitiba em suas múltiplas inter-relações. 2006. $316 \mathrm{f}$. Tese de doutorado (Programa de Pós-Graduação em Meio Ambiente e Desenvolvimento Rural) - Universidade Federal do Paraná. Curitiba, 2006.

CHAPECÓ. Plano de Desenvolvimento Rural de Chapecó- PDRC. Art. 31 do Plano Diretor de Chapecó. 2015. Disponível em: < https://web.chapeco.sc.gov.br/documentos /?f=/ Sedema/Plano\%20de\%20 Desenvolvimento\%20Rural.pdf >. Acesso em: 10 jan. 2016.

CHAYANOV. A Alexander. V. La Organización de la Unidad Económica Campesina. Buenos Aires: Nuevas Visión, 1974, 339 p.

GEERTZ, Clifford. Uma descrição densa: por uma teoria interpretativa da cultura. In: Interpretação das culturas. Rio de Janeiro: LTC, 2008.

GIDDENS, Antony. As Consequências da Modernidade. São Paulo: UNESP, 1991. . Modernidade e Identidade. Rio de Janeiro: Jorge Zahar, 2002.

GIL, Antônio. Como Elaborar Projetos de Pesquisa. $4^{\circ}$ Edição. São Paulo: Atlas, 2002.

GODOY, Wilson I. As feiras-livres de Pelotas, RS: Estudo sobre a dimensão sócioeconômica de um sistema local de comercialização. 2005. 284 f. Tese de Doutorado (Programa de Pós-Graduação em Ciências) - Faculdade de Agronomia "Eliseu Maciel"- Universidade Federal de Pelotas, Pelotas, 2005.

SILVA, J. GRAZIANO da. A industrialização e urbanização da agricultura brasileira. Artigo apresentado no projeto Iris/Desep-CUT, 1993.

IBGE (Instituto Brasileiro de Geografia e Estatística). Censos Demográficos. 2010. Disponível em:<http://cidades.ibge.gov.br/>: Acesso em: 10 jun. 2015.

LAMARCHE, Hughes (Coord.). A agricultura familiar: Comparação internacional. Tradução de Ângela Maria NaokoTijiwa. Campinas: Ed. da UNICAMP, 1993, p.11 - 33. In: WANDERLEY,M.N.B. Agricultura familiar e campesinato: rupturas e continuidades. Estudos Sociedade e Agricultura, Rio de Janeiro, n.21, p. 42-61, out. 2003.

MAUSS, Marcel. Ensaio sobre a dádiva: formas e razão da troca nas sociedades arcaicas. São Paulo: CosacNaify, 2013.

MENDRAS, Henri. Sociedades Camponesas. Rio de Janeiro: Zahar, 1976.

MIOR, LUIZ. C. Agricultores familiares, agroindústrias e território: a dinâmica das redes de desenvolvimento rural no oeste catarinense. 2003. 315f. Tese de 
Doutorado (Centro de Filosofia e Ciências Humanas) - Universidade Federal de Santa Catarina, Florianóolis, 2003.

PEREIRA, C.J.; FREDDO, A.C. Oeste Catarinense História dos seus Empreendedores. Revista eGesta, v. 3, n. 3, jul.-set./2007, p. 32-76. Disponível em:< http://www.unisantos.br/mestrado/gestao/egesta/artigos/114. pdf $>$. Acesso em: 10 jun. 2015.

PLOEG, Jan D.V. Camponeses e impérios agroalimentares: lutas por autonomia e sustentabilidade na era da globalização. Porto Alegre: Editora da UFRGS, 2008.

. Trajetórias do desenvolvimento rural: pesquisa comparativa internacional. Sociologias, Porto Alegre, ano 13, n.27, mai./ago. p. 114-140, 2011.

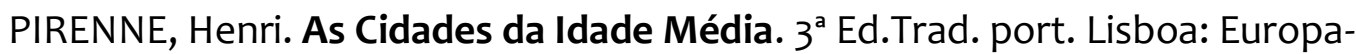
América,1973.

RECHE, D.; SUGAI, M.I. A influência do capital agroindustrial na distribuição sócioespacial urbana do município de Chapecó no sul do Brasil. In: COLOQUIO INTERNACIONAL DE GEOCRÍTICA, Barcelona, 10. Anais... Universidad de Barcelona, 26-30 de mayo de 2008. Disponível em:< http://www.ub.edu/geocrit/-xcol/257.htm>: Acesso em: 10 jun. 2015.

RICHARDSON, Roberto J. Pesquisa Social: Métodos e Técnicas. $3^{\circ}$ Edição. São Paulo: Atlas, 2008.

SABOURIN, Eric. Marcel Mauss: Da dádiva à questão da reciprocidade. Revista Brasileira de Ciências Sociais, São Paulo, v. 23, p. 131-138, fev. 2008.

. Sociedades e organizações camponesas: uma leitura através da reciprocidade. Porto Alegre: Editora da UFRGS, $2011 a$.

. Teoria da Reciprocidade e sócio-antropologia do desenvolvimento. Sociologias (UFRGS. Impresso), v. 27, p. 24-51, $2011 \mathrm{~b}$.

SACCO DOS ANJOS, Flávio. dos. Agricultura familiar, pluriatividade e desenvolvimento rural no sul do Brasil. Pelotas: EGUFPEL, 2003. 374 p.

TESTA, V.M. et al. A escolha da trajetória da produção de leite como estratégia de desenvolvimento do Oeste Catarinense. Florianópolis: SAR, 2003. 130p.

TOURAINE, Alain. Crítica da modernidade. Petrópolis, RJ: Vozes, 1994.

WANDERLEY, Maria N.B. Raízes históricas do campesinato brasileiro. XX ENCONTRO ANUAL DA ANPOCS. 1996. Caxambu. Anais... Disponível em:<http://comunidades.mda.gov.br/o/899445>. Acesso em: 10 jun. 2015. 
. Em busca da modernidade social: uma homenagem a Alexander $\mathrm{V}$. Chayanov. IN: FERREIRA, A.D.D.; BRANDENBURG, A. (Org). Para pensar outra agricultura. Curitiba: Editora da UFPR, 1998.

VEIGA, José. O processo de privatização da posse da terra indígena. Portal Kaingang, 2006. Disponível em: < http://www.portalkaingang.org/ privatização juracilda.pdf > Acesso em 10 jun. 2015.

WILKINSON, John. Mercados, Redes e Valores: o novo mundo da agricultura familiar. Porto Alegre: Editora UFRGS, 2008.

Hieda Maria Pagliosa Corona. Socióloga, Mestre em Sociologia e Doutora em Meio Ambiente e Desenvolvimento (UFPR); bolsista sênior da Fundação Araucária/SETI/Pr e Capes/Br; docente permanente do programa em desenvolvimento regional (PPGDR); pesquisadora e líder do Centro de Pesquisa e Apoio ao Desenvolvimento Regional (Centro de Pesquisa e Apoio ao Desenvolvimento Regional-CEPAD/ Universidade Tecnológica Federal do ParanáUTFPR).pagliosa@utfpr.edu.br

Samuel Tafernaberri Vasques. Universidade Tecnológica Federal do Paraná/Campus Pato Branco. Agrônomo na Prefeitura de Chapecó - End. Rua Nereu Ramos 1750E Sala dos Técnicos, Bairro Passo dos Fortes, Chapecó-SC, CEP 89805-100.stvasques@hotmail.com

Wilson Itamar Godoy. Engenheiro agrônomo, Mestre em Fitotecnia (UFRGS), Doutor em Agronomia (UFPEL); docente permanente do PPGDR, da Universidade Tecnológica Federal do Paraná (UTFPR), Campus Pato Branco; membro do CEPAD/UTFPR.wigodoy@utfpr.edu.br 